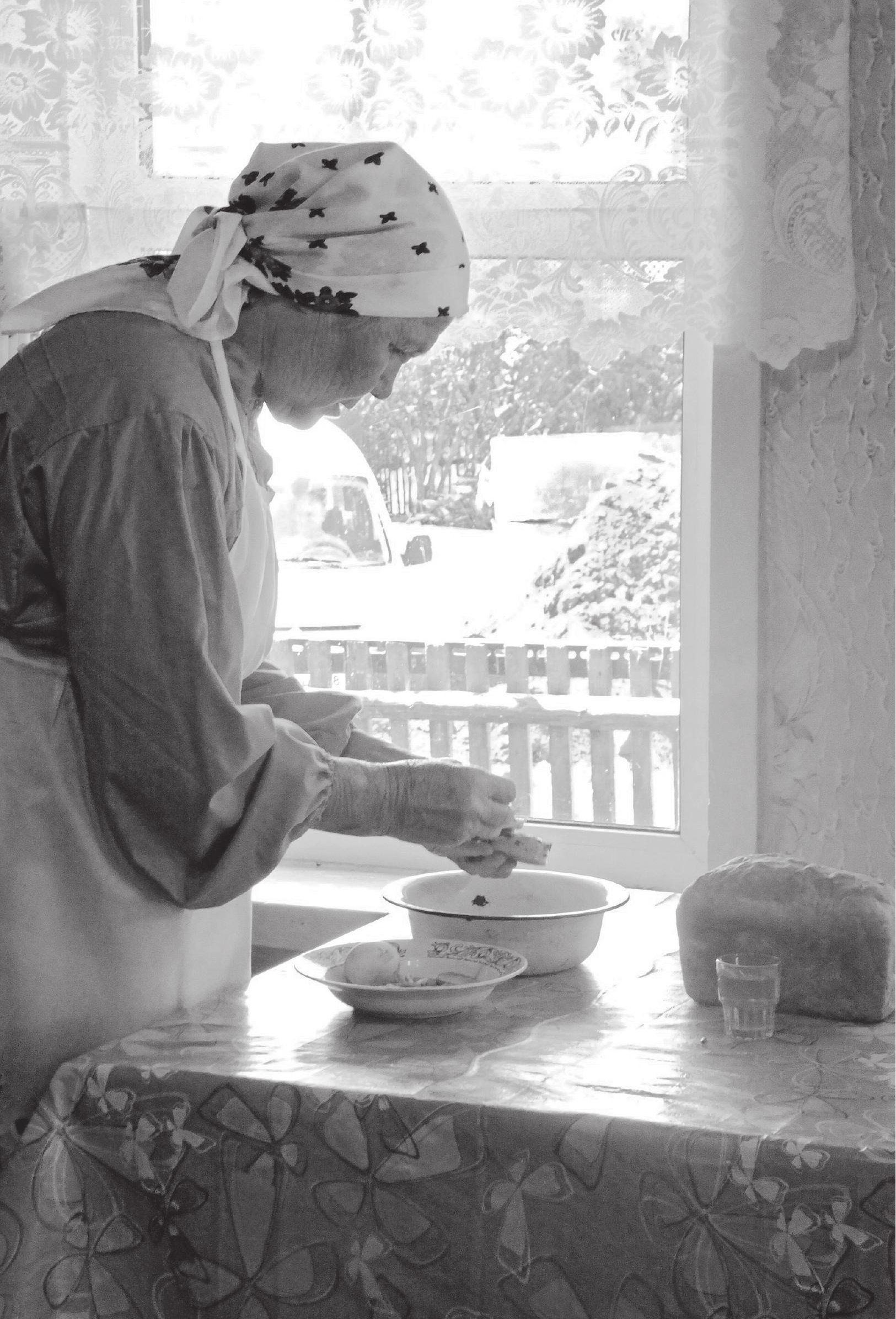




\section{Mälestamisrituaal tšekan nüüdisaegse udmurdi küla etnokultuurilisel maastikul}

Nikolai Anisimov

Teatavasti kujuneb rahva etnokultuuriline maastik lähtuvalt tema usundilis-mütoloogilistest arusaamadest ja traditsioonilisest maailmavaatest. Kalendrikombed ja rituaalide läbiviimise kohad reglementeeritakse ja lokaliseeritakse vastavalt territooriumi sümboolsetele paikadele ning arvestades piirkonna sakraalse geograafiaga.

Udmurdi traditsioonilises kultuuris on küla etnokultuurilise maastiku korralduses tähtis roll jõel või allikal. Seda kinnitavad nii teaduslikud tööd (vt nt Vladõkin 1994: 75-81, 219-220; Vladõkina 1997: 179; Vladõkina, Gluhhova 2011: 24-25, 63, 75, 104-106, 144-145; Anisimov 2017: 37) kui ka uusimad andmed autori välitöödelt. Etnokultuurilise maastiku struktuuris on selge ruumiline gradatsioon: keskel on inimeste elupaik, ülesvett jääb ülemise ilma ala ja allavoolu paikneb allmaailm ehk surnute maailm.

Artiklis on vaatluse all eripäraste surnute (võõrsil või ebaloomulikult surnud) mälestamise kombetalitus tšekan, mis on levinud üsna kitsal alal, Udmurtia Vabariigi Kijasovo rajooni Kalašuri (udm Vuž Tigõrmen) ja Dubrovski (udm Võl' Tigõrmen) külas ning kindlalt seotud rahvakalendriga.

Uurimus põhineb autori välitöömaterjalidel (kogutud aastatel 2008, 2012 ja 2016), Udmurdi Riikliku Ülikooli udmurdi filoloogia teaduskonna murdearhiivi materjalidel ja olemasoleval kirjandusel. Samuti toetub autor isiklikele tähelepanekutele, olles pärit samast piirkonnast ja tundes kohalikku traditsiooni. Informantideks on olnud kohalikud elanikud vanuses 50-90 aastat, enamasti naised, sest just need inimesed on rahvakommete aktiivsemad hoidjad ja rituaalsete toimingute taasesitajad. Eriti väärtuslikud on nimetatud külades sündinud ja kasvanud informantidelt saadud andmed, kuna need võimaldavad näidata uurimisobjekti ka diakrooniliselt.

Uurimuses on rakendatud kompleksset lähenemist, mis kasutab etnograafilise, folkloorse, antropoloogilise ja etnolingvistilise analüüsi meetodeid. Selline valik on

Mälestamine kodus. Udmurtia Kijasovo rajooni Kalašuri küla. 
tingitud traditsiooni suulisest loomusest, sest elav traditsioon on lahutamatult seotud keele, teksti ja rituaaliga.

Välitöödel on kasutatud foto- ja videokaamerat ning digitaalset diktofoni. Talletatud materjalidest monteeritud film 2008. aasta kombetalituse kohta on nähtav ka veebisaidil YouTube (vt Obrjad 2008). 2012. aastal teleraadiokompanii Моя Удмуртия poolt jäädvustatud ja filmiks monteeritud rituaal on samuti kättesaadav internetis (vt Tšekan 2012), mõnd fragmenti saab vaadata ka YouTube'is (vt Obrjad 2012). Põhiosa kogutud materjalist ja välitöödel tehtud intervjuudest (foto-, video- ja helifailid) on autori isiklikus arhiivis.

\section{Etümoloogia}

Tänapäevases udmurdi keeles on tšekan deetümologiseerunud sõna, kuid teadlased on rekonstrueerinud tšek-tüvega ja selle variantidega sõnade tähendust: чеке, чеканы/чекаськыны, чокмор, чокмар, чокморскон/чокморъяскон, четкер/чекер/ черкке/чекерйыл/чекерил jne (Vladõkina 1997: 42; Lintrop 2003: 151-152; Gluhhova 2004: 150-153; Vladõkina, Gluhhova 2011: 137-139). Analüüsimata siin igat mõistet eraldi, võib nentida, et nendel sõnadel on turgi juured ja kultuurimärgina tähendavad nad ohvri pakkumist või ohverdamist surnute hingedele (Vladõkina, Gluhhova 2011: 137-138). Oluline on arvestada keeleüksuse (sõna) ja kultuurimärgi tõlgendamise eripäraga (Tolstaja 2010: 7-19). Arvan, et viimane pakub traditsioonilise rahvakultuuri uurimisel suuremat huvi, sest võimaldab avada vaadeldava kultuuriobjekti semantilis-sümboolset sisu etnolingvistilise maailmakäsitluse kontekstis. Ei tohi jätta tähelepanuta ka seda, et kõikjal udmurtide asualadel leidub topograafilisi objekte, mille nimes on kasutatud seda tüve või selle variante. Folklorist Tatjana Vladõkina tõlgendab neid esivanemate rituaalse mälestamisega seotud paikadena kõrgemates kohtades või vanadel kalmistutel (Vladõkina 1997: 42; Vladõkina, Gluhhova 2011: 138). Galina Gluhhova lisab, et need mõisted on tihedalt seotud ettekujutustega surnud esivanemate hingedest ja aktualiseeruvad teatud kalendriperioodidel teatud rituaalsel alal (Gluhhova 2004).

Kokkuvõttes võib öelda, et tšekan on spetsiaalne mõiste (kultuurimärk), mis tähistab esivanematele suunatud eripärast sakraalset tegevust (atribuut + sõna + toiming) traditsiooniga määratud ajal ja kohas.

\section{Kombetalituse rituaalne sisu}

Informantide sõnul mälestatakse selle kombetalitusega oma küla inimesi, kes surid mujal ja pole seepärast maetud kohalikule kalmistule, aga ka enesetapu sooritanuid. Ilmselt peitub selles inimeste soov mitte jätta oma „erilisi“ surnuid tähelepanuta kriisihetkedel (sellest allpool), kui nad võivad avaldada halba mõju elavatele. Võib oletada, et selle mälestamisohverdamisega avaldatakse seda sorti surnutele austust, sest ühistel ega perekondlikel mälestamispäevadel neile eraldi ande reegli- 
na ei anta. Teisisõnu, neid nii mälestades hoiavad elavad selle surnute kategooriaga sidet ja nõnda ei muutu need surnud deemonlikeks hingedeks.

Teaduslikest allikatest (Vladõkin 1994: 243; Lintrop 2003: 212), dokumentaalfilmidest (Veka 2006) ja autori 2017. aasta välitööde materjalidest selgub, et taoline väljaspool oma asulat surnud inimeste spetsiaalse mälestamise rituaal on tänapäeval täheldatav ka Tatarstani Agrõzi rajooni Varkled-Bodja külas. Kombetalitus kannab seal nime Сьӧрло/-н кулэмъёслы куяськон 'võõrsil surnute mälestamine' või Куяськон 'peied' ja on lõpupalvuseks adrapeole Гершыд pühendatud iga-aastases kevadsuviste palvuste tsüklis (Vladõkin 1994: 243; Lintrop 2003: 212). Nagu kombetalitust tšekan, peetakse sedagi mälestamist kohas, mis jääb palvuste paigast allavoolu. On ka erinevusi: kui Varkled-Bodja udmurtidel „oli see varem endise kodumaa sugulaste mälestamine“ (Vladõkin 1994: 243), ei puutu ebaloomulikult surnutesse ja toimub igal aastal, siis Kalašuri ja Dubrovski udmurdid viivad oma kombetalitust läbi kord nelja aasta jooksul. Sarnaseid jooni leidub ka lahkunud vanemale pühendatud mälestamisohverdusega Йыр-пыд сётон '[looma] pea ja jalgade andmine', kuid seal mälestatakse ainult üht lahkunut ja see kuulub sügistalvisesse perioodi, tšekan pühendatakse aga paljudele „erilistele“ surnutele ja toimub juunikuus. Teaduskirjanduses on ka teisi sarnase nimega ja teatud määral lähedasi mälestustseremooniaid (Чокаськон/Чекаськон), kuid ühtki neist enam ei peeta (Vereštšagin 1997: 248-249; Šutova 2001: 44, 46, 88).

Paralleele võib leida ka naaberrahvastelt: vene, tšuvaši, mari, sürja- ja permikomi kultuurist (vt nt Zelenin 1995: 129-140; Toidõbekova 1997: 298-300; Toidõbekova 2007: 243-244; Pantšenko 2008: 232-259; Tšugajeva 2008: 260-271). Udmurdi kombetalitusele tšekan tundub kõige lähedasem olevat mari mälestamisrituaal Утымлан пуымаш 'pidu sugulasteta surnutele', mis viiakse läbi igas külas kord kolme aasta tagant (Toidõbekova 1997: 298-300; 2007: 243-244). Mälestamisel tuuakse must pull, jäär või lammas ohvriks kaugetele esivanematele, kelle sugulusastet pole enam võimalik kindlaks teha (samas). Uurides pere poolt mälestamata jäänud või sugulaste ja lähedaste poolt unustatud surnute kultust, jõuab Aleksandr Pantšenko õigete järeldusteni, et taolistes kultuurinähtustes mängib erilist rolli elanikkonna suhtumine vanadesse ja/või mahajäetud kalmistutesse, arheoloogilistesse mälestistesse, mis on tihti kohalikud pühapaigad. Selle surnuterühma austamist tasub vaadelda mitte essentsialistliku ettekujutusena, vaid lokaalse ja regionaalse kultuurivormina; nende surnute mälestamine ei nõua mitte üksikisiku või perekonna tähelepanu, vaid kollektiivi (kogukonna) osavõttu (Pantšenko 2008: 232-259).

Kombetalitus koosneb mitmest etapist. Vaatame neid lähemalt.

Maja ettevalmistamine. Päeva esimeses pooles käivad igas majas ettevalmistused kombetalituseks: valmistatakse peietoitu (küpsetised, kanasupp või nisupuder jm), toimub mälestamine pereringis. Lauaotsa asetatakse pits alkoholi (tavaliselt puskar), mida valatakse üle käeselja, pöördudes samas surnute poole. Jook kannab nime пересь вина 'esivanemate vein' ja on mõeldud surnutele. Pitsi kõrval on suur taldrik, kuhu pudistatakse, samuti üle käeselja, erinevaid sööke ja palutakse surnud sööma. Kui kõik täiskasvanud pereliikmed on need toimingud (куяськон 'viskamine, kinkimine') ära teinud, viib perepea või vanim pereliige annid talu piiridest 
väljapoole ja kallab need lääne või põhja suunas. Seal lausutakse taas vormeleid, paludes võtta annid vastu ja tagada elavatele hea elu.

Ohverdamine. Varahommikul enne koitu toovad mehed ohvriks pulli või vasika. Vanemad inimesed meenutavad, et kuni 20. sajandi keskpaigani oli ohvriloomaks hobune, kes veristati juba eelmisel õhtul ja kelle liha keedeti öö läbi. Ohvriloom asetatakse peaga lääne või põhja suunas, veri lastakse maha või kallatakse mälestamiskuuse alla. Lihaga keedetakse putru või suppi, pea ja jalad jäetakse rituaalseks anniks.

Põhiosa. Lõunaks kogunevad kombetalituse paika Kalašuri ja Dubrovski elanikud, teistesse küladesse mehele läinud naised ja mujal elavad nendest küladest pärit inimesed. Toimub куяськон - kogunenud rahvas, välja arvatud lapsed ja vallalised noored, toob joogiohvri (kahja) ja toidab rituaalselt lahkunuid. Kõik seisavad anumate ümber ja pudistavad sinna kaasatoodud küpsetisi, panevad osa pudrust ja supist, kallavad alkoholi, mälestades samal ajal lahkunud omakseid ka sõnadega. Kõik toimingud toiduga sooritatakse üle käeselja, et palved ja annid „jõuaksid kohale" surnute ilma. Toiduandide kõrvale süüdatakse leivatükki kinnitatud vahaküünal.

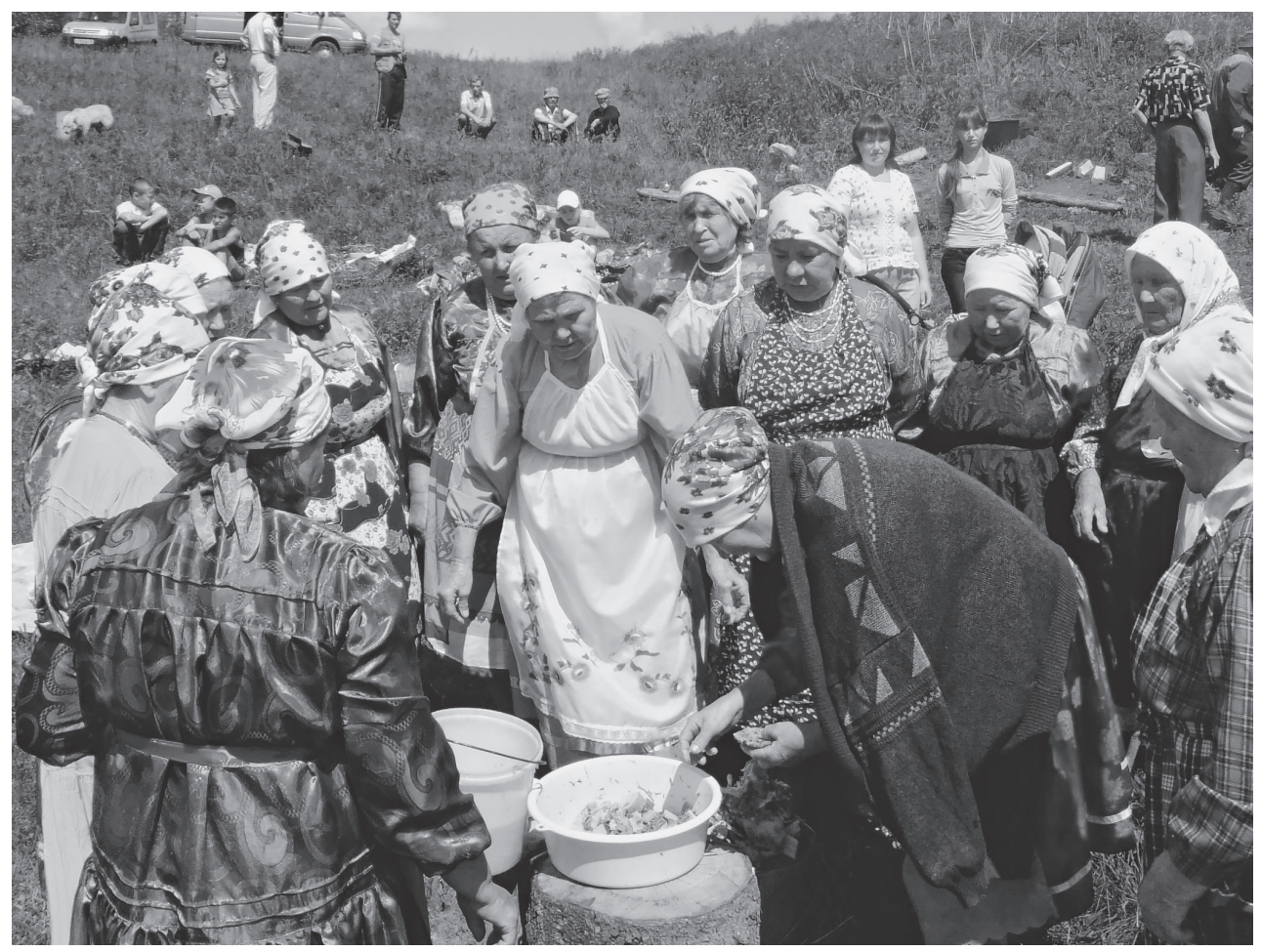

Rituaalne laulmine ja mälestamine Udmurtia Kijasovo rajooni Kalašuri külas.

Foto: Mirela Mazu 2012 
Siinsamas lauldakse rituaalseid laule кисьтон гур 'peielaul' ја чекаськон гур 'tšekan'i [peie]laul'. Viimane lauldakse pulmalaulude (сюан гур ја ярашон гур) viisiga, pöördudes lahkunute poole erinevate palvetega. 2008. aasta kombetalituselt talletati näiteks järgmised laulud:

\section{Чекаськон гур 'tšekan'i [peie]laul'}

Та сётыләм животмес кияды( й) кутәлә.

Бер кылем но животлес гид тыр, луд тыр карелэ.

Бер кылем но животмес гид тыр, худ тыр карелэ.

Ой, зеч улә, ӟеч улә сояз(ъ) но(и) дунне(й)ьн,

Бер кылем но семьядылия(й) азинльк но сётәлэ.

Бер кылем но семьядылы азинлык но сётәлэ.

See [meie] antud loom võtke oma kätte.

Siia jäänud kari mitmekordistage.

Siia jäänud kari mitmekordistage.

Oi, elage hästi, elage hästi seal ilmas,

[Teie] siia jäänud perele andke edu.

[Teie] siia jäänud perele andke edu.

(Anisimov, Veršinina, Ptšelovodova 2011: 85-86; Udmurdi Vabariigi Kijasovo rajooni Kalašuri küla)

Бер кылем но нылииль тазальк но сётәлэ,

Гурто гынэ кальыклы азиньлькссә сётәлэ.

Гурто гынэ калыкмылы азиньлыксә сётэлә.

Кизьыләм но ю-няньль небыт зорзэ мед сётоз,

Кизьыләм но, ой, ю-няньмь ӟеч гынэ мед удалтоз.

Кизьыләм но, ой, ю-няньмы ӟеч гынә мед удалтоз.

Siia jäänud lastele kinkige tervist,

Oma küla rahvale kinkige õitsengut.

Meie küla rahvale kinkige õitsengut.

Külvatud viljale kinkige pehmeid vihmasid,

Külvatud vili kasvagu hästi.

Külvatud vili kasvagu hästi.

(Autori välitöömaterjal, Udmurdi Vabariigi Kijasovo rajooni Kalašuri küla, 2008)

\section{Кисьтон гур}

Та вордьләм әль вылә но

Кыле лёгем пьтие.

Пёгем пьтие мар гынэ но,

Кыле ёзэ-кальке.

Улом валче, туганэ, но,

Вылом валче, туганэ.

Ум ведь улэ, ум ведь улэ

Аюгыт дунне сисьмытозь. 
Аюгыт дунне, ой, сисьмытозь,

Асьмеос но ум улэ.

Асьмелән но выльёсамы

Вож бадьёс но потозы.

Шулдыр гужем, шулдыр гужем,

Тылобурдо чирдыку.

Чиге выләм пинял сюләм,

Эиъёс тодэ лькктыку.

Ӧй тӥя вал италмасэз,

Уз ик тӧлӟы кожаса.

Ӧй вера вал веран кылме,

Ум люкиське шуыса.

Ой, бадяр куар, бадяр куар но,

Пасьтана усем бадяр куар.

Пасьтана усем бадлр куар кадь,

Туннә асьмес пазьгиськом.

\section{Peielaul}

Siia armsasse kodukanti

Jäävad mu jäljed.

Mida on [väärt] mu jäljed,

Jäävad mu eakaaslased, mu rahvas.

Hakkame elama koos, omaksed,

Hakkame koos, omaksed.

Me ei ela ju, me ei ela ju

Aegade lõpuni.

Aegade, oi, lõpuni

Ei ela me.

Meie kalmudele

Kasvavad rohelised pajud.

Lõbus on suvi, lõbus on suvi,

Kui linnud laulavad.

Süda nukrutseb,

Kui meenuvad sõbrad.

Ei murdnud ma kullerkupuõisi,

Arvates, et nad ei varise maha.

Ei öelnud ma salajasi sõnu,

Arvates, et lahku me ei lähe.

Oi, pajulehed, pajulehed,

Laiali pudenenud pajulehed.

Justkui laiali pudenenud pajulehed

Täna me läheme lahku.

(Autori välitöömaterjalid, Udmurdi Vabariigi Kijasovo rajooni Kalašuri küla, 2008) 
Need kohustuslikud laulud saadavad rituaalil osalejate tegevusi ja ütlemisi. Kontakteerumisel surnute ilmaga toimib laulmine suhtlemisvahendina ja on omamoodi „looritatud kõneks", mis konstrueerib maailmadevahelist dialoogi (vt lähemalt Anisimov 2017: 220-229).

Lahkunute ärasaatmine. Kui kõik osalejad on toonud kahja, viiakse mälestamisannid pühapuu tšekan kuuse (чекаськон/чекан/куяськон кыз) јuurde'. Siin jätavad elavad lahkunutega hüvasti (келиськон) kuni järgmise kombetalituseni.

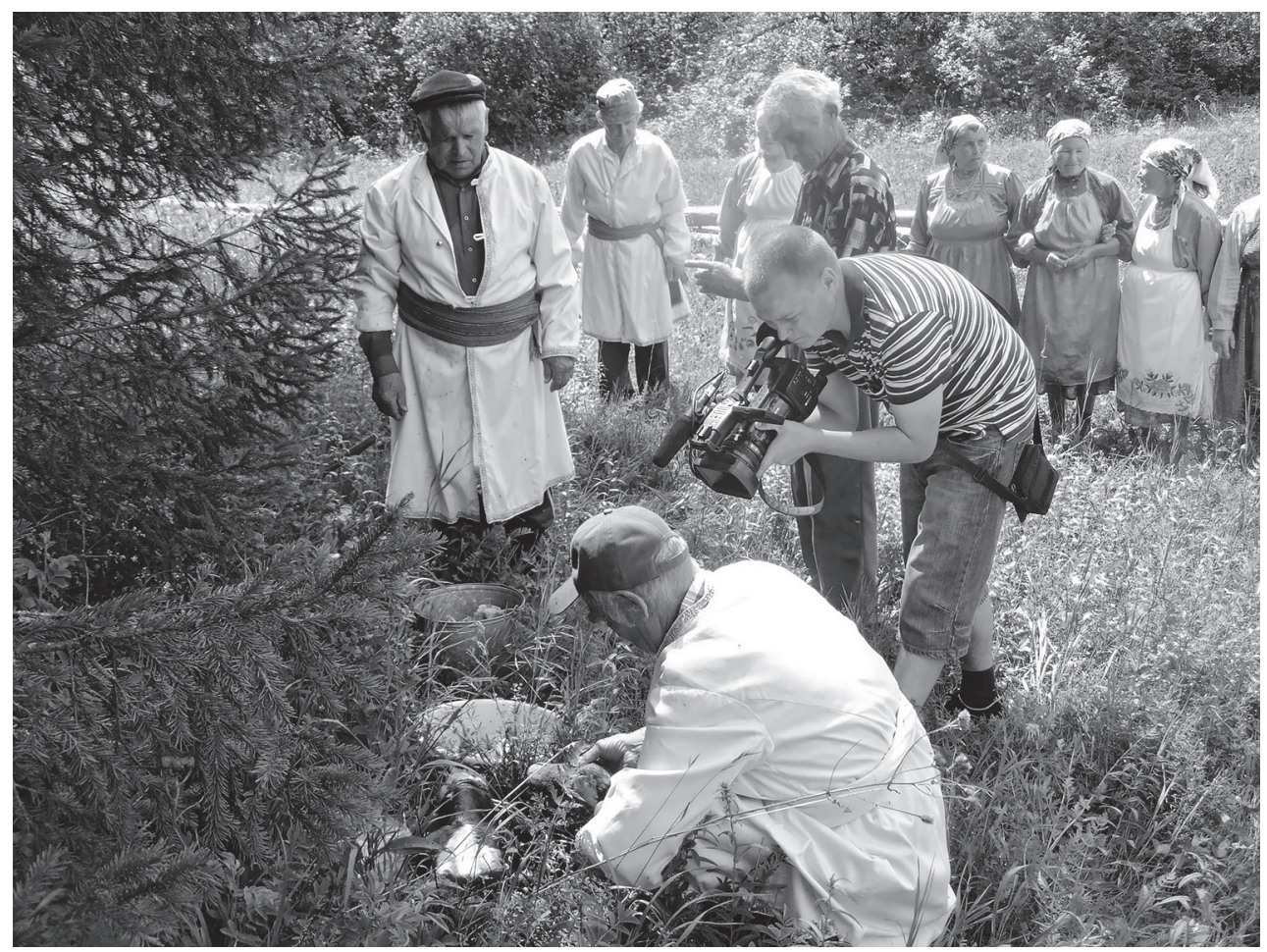

Lahkunute ärasaatmine ja andide andmine. Udmurtia Kijasovo rajooni Kalašuri küla.

Siia jäetakse ohvrilooma pea ja jalad, kallatakse peietoidud ja -joogid, siin lauldakse taas peielaule ja mälestatakse lahkunuid. Tuleb märkida, et looma pea asetatakse jõe suhtes pärivoolu, esijalad pannakse ette ja tagajalad taha, s.o imiteeritakse looma. Sellisel viisil osutatakse looma hingele liikumise suunda - surnute ilma. Pärast hüvastijätuosa minnakse tagasi lagendikule, kus toimus rituaali esimene osa. Viimasena lahkub vanem meesterahvas ja teeb riste rajale, mida mööda inimesed siia tulid. Nõnda toimides pöördub ta surnute poole palvega, et need ei järgneks elavatele, vaid ootaksid, kuni elavad tulevad ise taas neid mälestama. Nõnda tõmmatakse piir kahe maailma vahele ja mälestamise tseremoonia lõpeb.

Lõpuosa. Lagendikul algab ühissöömine, mis läheb üle lõbutsemiseks. Reeglina söövad üheskoos sugulaste rühmad. 


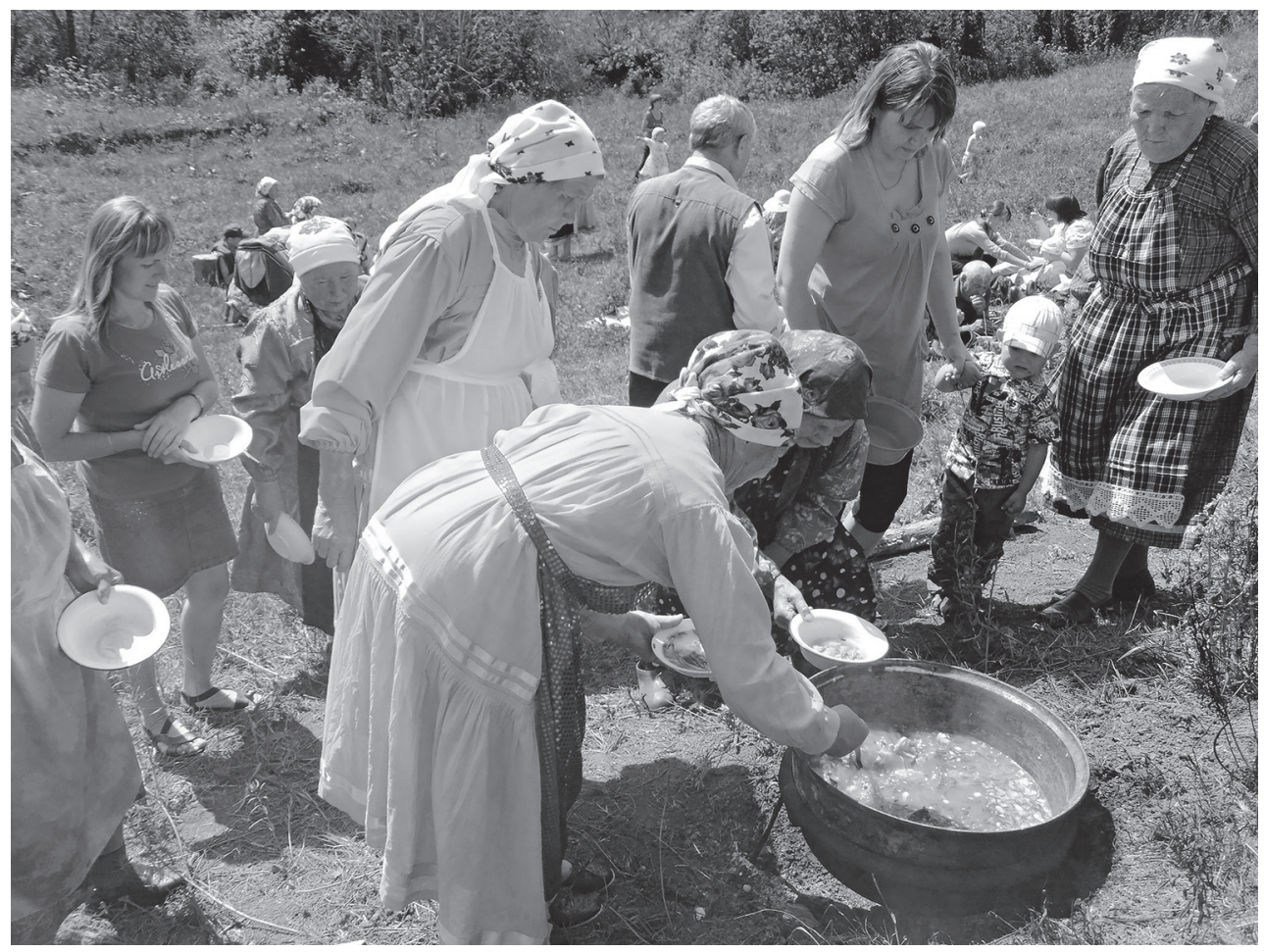

Peiesupi jagamine. Udmurdtia Kijasovo rajooni Kalašuri küla.

Foto: Mirela Mazu 2012

Vanemad elanikud meenutavad, et seda kombetalitus peeti „pidulikuks“, sest kogunes palju rahvast ja valitses lõbus õhkkond. Pärast lahkunute hingede ärasaatmist mängiti ringmänge ja muid mänge, tantsiti, lauldi, lõbutseti, suheldi ja kostitati üksteist alkohoolsete jookidega.

\section{Osalejad}

Rituaalist võtavad osa Kijasovo rajooni Kalašuri ja selle tütarküla Dubrovski elanikud, samuti nendest küladest pärit, kuid võõrsil elavad inimesed. Vanemate inimeste sõnul käisid 20. sajandi lõpuni kombetalitusel ka naaberkülade Lutohha ja Sabantšino vene elanikud. Peamiste sakraalsete toimingute ajal seisid nad eemal ja ühinesid seejärel teiste pidulistega. Tänapäeval võivad võõrad kohal olla, kuid neil ei lubata võtta osa mälestamise põhietappidest куяськон 'kahja toomine' ја келиськон 'lahkunute ärasaatmine'. Osaleda ei lubata ka lastel ega vallalistel noortel.

Kuni 20. sajandi keskpaigani juhtis kogu mälestamisprotsessi (animistlik) preester. Tema oli ka see, kes kutsus külarahvast kombetalitusele, andes sellest teada, kolistades puunuiadega või lüües vastu raudeset, kui suundus pühapaika. Tänapäeval on tseremooniameistriteks vanemad külaelanikud. 


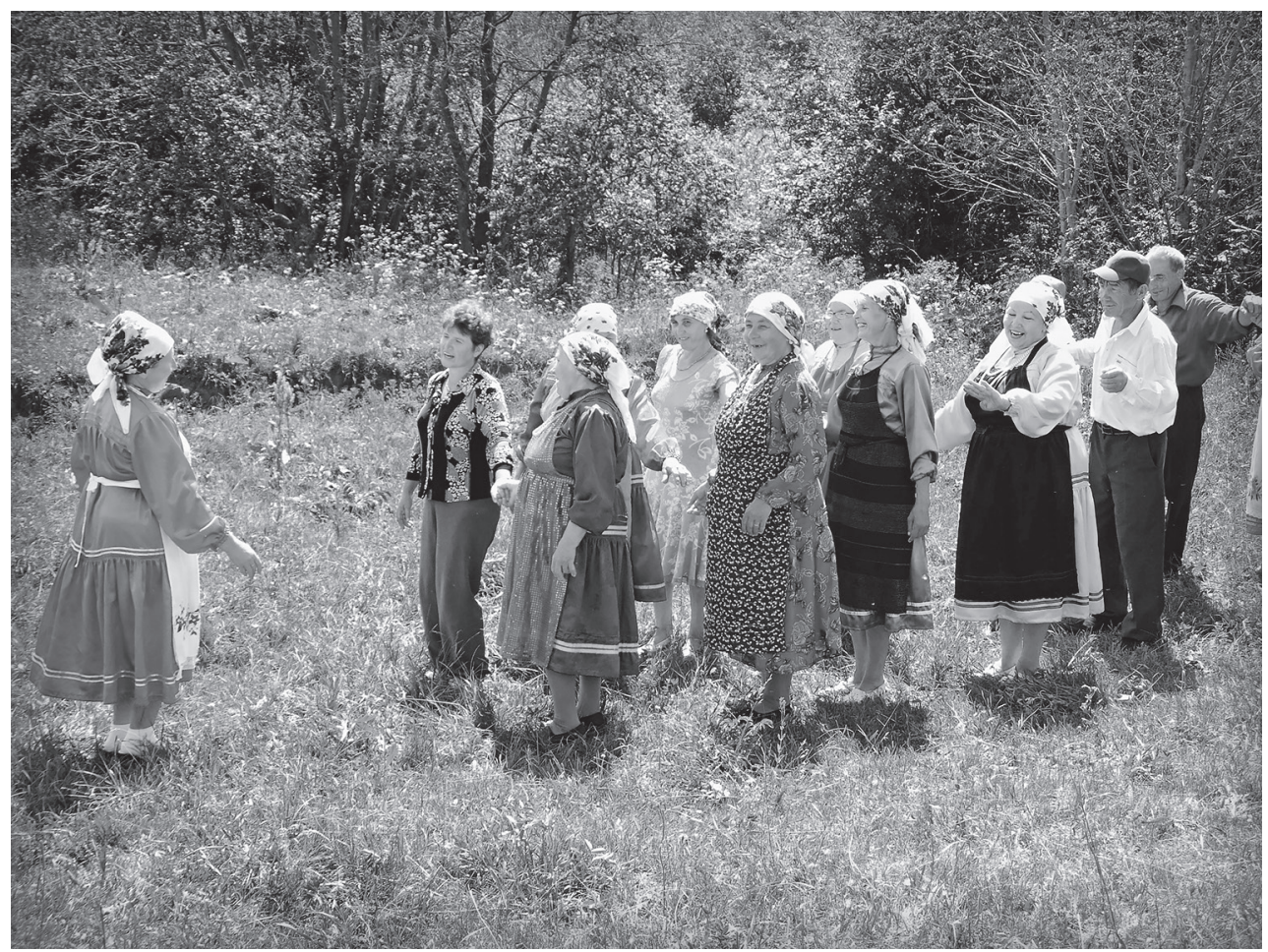

Rituaalijärgne mäng. Udmurtia Kijasovo rajooni Kalašuri küla.

Foto: Mirela Mazu 2012

\section{Toimumisaeg}

Rituaali aeg on kindlalt reglementeeritud. Tšekan'i korraldatakse juunis pärast kevadiste põllutööde lõppu tähistavat pidu ja ainult liigaastal. Juunikuu on udmurdi rahvakalendris pöördeline periood, mida tähistab suvine pööripäev ja mis peegeldub ka kuu nimetuses инвожо толэзь '[üleminekuaja] taevavaimude вожо kuu'. Usuti, et siis laskusid ülemise/taevase ilma vaimud maa peale. Kombetalituse ajastamist liigaastale (касиян / касъян ap) põhjendavad informandid sellega, et liigaastat peetakse raskeks ja selle „kergendamiseks“ toimubki rituaal. Arvatavasti toimus tšekan enne iga kolme aasta tagant nagu ka Чокаськон/Чекаськон Malaja Purga ja Možga rajooni udmurtidel (Vereštšagin 1997: 248-249; Šutova 2001: 44-46; 88), kuid hiljem ajastati see liigaastale, viidates selle aasta semantikale.

Informandid meenutavad, et Teise maailmasõja tõttu oli kombetalitus kadumas, kuid pärast üht onnnetust (toimumise aega ei täpsustata) hakati seda jälle korraldama. Nimelt jäi rituaalipaiga lähedal sohu kinni ja hukkus täkk. Kohalikud nägid selles halba märki ja otsustasid mälestamisohverduste pidamist jätkata.

Tšekan'i ajastamine tänapäeval liigaastale pole juhuslik. Kombetalituse ajakoodil on piiripealsuse, ohtliku ja raske aja tähendus. Traditsiooni seisukohalt sobib see aeg mälestamaks teatud mõttes liminaalsesse kategooriasse kuuluvaid surnuid ehk 
ebaloomulikult või võõrsil surnud ja mujale maetud oma küla inimesi (кыре-буре / палэнэ кулэмъёс).

\section{Toimumispaik}

Tšekan'i toimumiskoht paikneb Kalašuri külast allavoolu ühe künka jalamil allika kõrval, kus kõik ümbritsevad topograafilised objektid viitavad sellele rituaalile: чекан возь 'tšekan'i niit', чекан ошмес 'tšekan'i allikas', чекан / чекаськон кыз 'tšekan'i/mälestamise kuusk', чекан нюр 'tšekan'i soo'. Selle lähedal tšekan'i toimumiskoha ja küla vahel on üks teine sakraalne paik Aktaš, kus on kunagi korraldatud palvusi jumal Aktaš'ile. Külale lähemal asub ühel künkal ka nimeta kalmistu - нимтэмшай. Vestlustest informantidega selgub, et seda paika mäletavad veel vaid vanema põlvkonna esindajad.

2008. ja 2012. aastal toimusid rituaalid teistes kohtades (vt kaardid). 20. sajandi lõpuni toimusid tseremooniad oma esialgses kohas, kuid hiljem nihkusid nad Kalašuri külale lähemale. 2008. aastal viidi kombetalituse põhietapid, välja arvatud lahkunute hingede ärasaatmine, andide rituaalne viimine püha kuuse alla ja pidu, läbi umbes samas kohas, kus 20. sajandi alguseni toimus kurjale jumalale Aktaš'ile pühendatud rituaal.

2012. aastal toimus tseremoonia esimene osa küla lõpus ning lahkunute ärasaatmine ja andide jätmine juba Aktaš'i paigas, s.o tšekan'i algkohale ei jõutudki. Rituaalijärgne pidu jätkus samas, kus rituaali esimene osagi. 2016. aastal toimus kõik samas järjekorras ja samades paikades nagu 2012. aastal.



Kaart 1. Kombetalituse toimumispaik 2008. aastal 


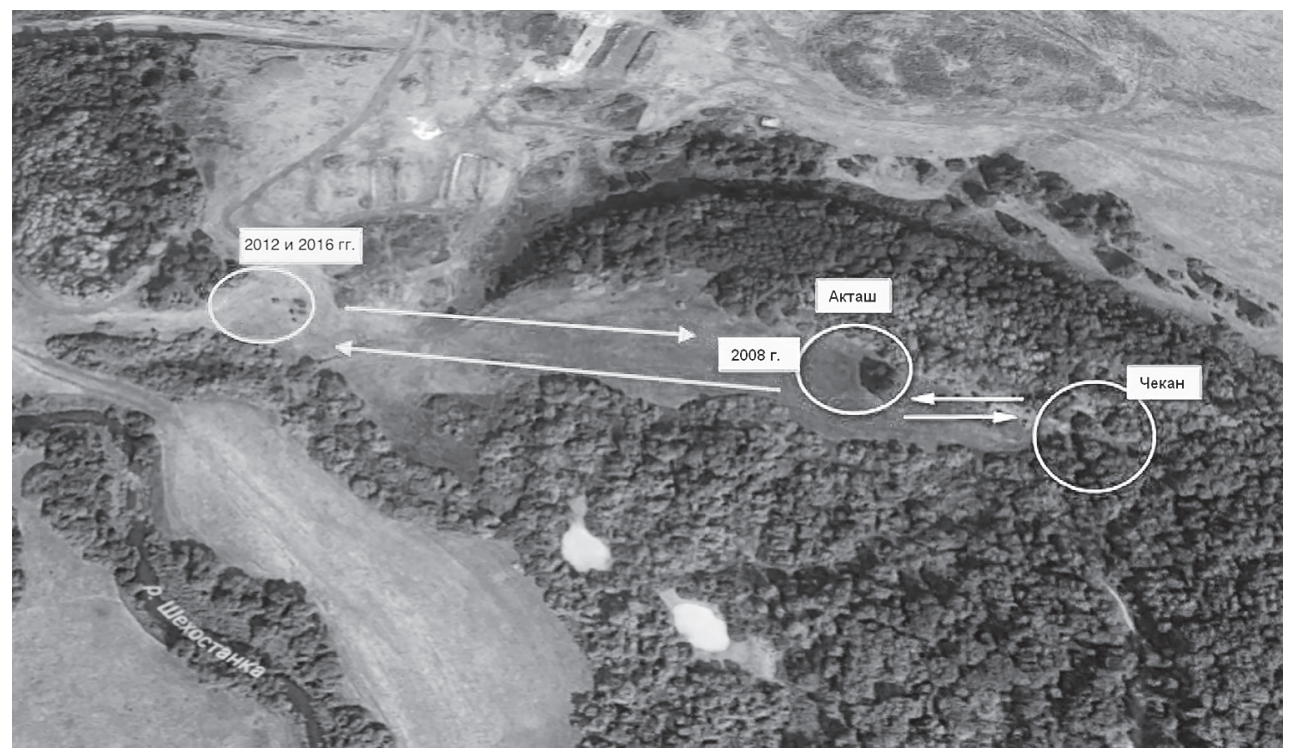

Kaart 2. Kombetalituse toimumispaik 2012. ja 2016. aastal

Vestlustest informantidega selgus, et rituaali tšekan toimumiskoha muutmisega laieneb sakraalne ala ja kujuneb küla etnokultuurilise maastiku uus pilt. Seejuures säilib rituaali teiste toimumiskohtade sakraalsus ja samas saavad sakraalse koha staatuse uued paigad, kus kombetalitused viimastel aastatel toimusid. Seega saab Aktaš'i koht topeltsakraalseks. Ent kuna Aktaš'i mäletavad vaid vanemad inimesed, ei ole see nooremate jaoks aktuaalne ja aegamööda kaob rituaal küla kultuurimaastikult ära. Kokkuvõttes selgus, et aktiivsed teadmised praeguste rituaalsete praktikate kohta on tulnud vanemate asemele.

Mis on kombetalituse koha muutmise põhjus? Informandid teatavad, et kuna rituaal toimub iga nelja aasta tagant ehk harva, on selle toimumiskoht võssa kasvanud, ligipääs algsesse pühapaika on raskendatud ja mälestamispuud leida on keeruline. Teine põhjus peitub selles, et kombetalitusest võtavad osa enamasti vanemad inimesed, noori on järjest vähem ja mujale elama asunud rahvas ei käi seal enam peaaegu üldse. Kõik see on ajendanud külarahvast tegema muutusi küla etnokultuurilisel maastikul.

Kokkuvõtteks võib öelda, et Kijasovo rajooni udmurtide lokaalse rühma kalendrikombestikku kuuluv mälestamisrituaal tšekan on muutumas ja ühes sellega muutub ka küla kultuurimaastik. Sakraalse sfääriga seotud ruumilised muutused mõjutavad omakorda inimeste käitumist ja selle reglementeerimist ajas ja ruumis.

Vene keelest tõlkinud Nikolai Kuznetsov 


\section{Allikad ja kirjandus}

Anisimov 2017 = Анисимов Николай. 2017. «Диалог миров» в матрице коммуникативного поведения удмуртов. Tartu: University of Tartu Press.

Anisimov, Veršinina, Ptšelovodova 2011 = Анисимов Н. В.; Вершинина Е. Б.; Пчеловодова И. В. 2011. Тигырменские мелодии: песни тигырменских удмуртов Киясовского района удмуртской Республики. Ижевск: Респ. Дом нар. творчества - Дом молодежи.

Lintrop, Aado. 2003. Udmurdi usund. Tartu: Eesti Rahva Muuseum.

Gluhhova 2004 = Глухова Галина Анатольевна. 2004. К этимологии слова «чокмор». Г. Е. Верещагин и этнокультурное развитие народов Урало-Поволжья. Сборник статей. Сост. В. М. Ванюшев, Т. С. Зыкина; отв. ред. В. М. Ванюшев. Ижевск: УИИЯ PAH, 150-153.

Obrjad 2008 = Film «Обряд «чекан» киясовских удмуртов». 2008. https://youtu.be/g3xjfccbd8 (viimati külastatud 3.04.2018).

Obrjad 2012 = Videokatked «Обряд «чекан» киясовских удмуртов». 2012. a) https://youtu. be/UChNwI1Z5WQ; b) https://youtu.be/TAKDoulMxYs (viimati külastatud 3.04.2018).

Pantšenko 2008 = Панченко Александр. 2008. «Заложные родители»: смерть, коллективная память и сакральное пространство. - Сакральная география в славянской и еврейской культурной традиции: Сборник статей. Редколлегия О. В. Белова (отв. ред.), В. В. Молчанова, В. Я. Петрухин, А. А. Чулкова. Выпуск 22 (академическая серия). Москва: Центр научных работников и преподавателе иудаики в вузах «Сэфер»; Институт славяноведения РАН, 232-259.

Šutova 2001 = Шутова Надежда Ивановна. 2001. Дохристианские культовые памятники в удмуртской религиозной традиции: Опыт комплексного исследования. Ижевск: УИИЯА УpO РAH.

Zelenin 1995 = Зеленин Дмитрий Константинович. 1995. Избранные труды. Очерки русской мифологии: Умершие неестественной смертью и русалки. Москва: Индрик.

Toidõbekova 1997 = Тойдыбекова Дидия. 1997. Марийская языческая вера и этническое самосознание. Joensuu: Joensuu yliopistopaino.

Toidõbekova 2007 = Тойдыбекова Аидия Семеновна. 2007. Марийская мифология: этнографический справочник. Йошкар-Ола: ОАО «МПИК».

Tolstaja 2010 = Толстая Светлана Михайловна. 2010. Семантические категории языка культуры: Очерки по славянской этнолингвистике. Москва: Книжный дом «Диброком».

Tšekan 2012 = Teleülevaade «Кто мы. Чекан». 2012. https://youtu.be/CDFgJRzbVKo (viimati külastatud 3.04.2018).

Tšugajeva 2008 = Чугаева Светлана. 2008. Важ важжез касьтылӧм - поминание предков на культовых местах коми-пермяков. - Сакральная география в славянской и еврейской культурной традиции: Сборник статей. Редколлегия О. В. Белова (отв. ред.), В. В. Молчанова, В. Я. Петрухин, Л. А. Чулкова. Выпуск 22 (академическая серия). Москва: Центр научных работников и преподавателе иудаики в вузах «Сэфер»; Институт славяноведения РАН, 260-271.

Veka 2006 = Ajaloolis-etnograafiline film «Века и вехи». 2006. https://youtu.be/-5BVN3JaYyU (viimati külastatud 3.04.2018).

Vereštšagin 1997 = Верещагин Григорий Егорович. 1997. Собрание сочинений. Т. 3. Этнографические очерки. Кн. 1. Ижевск: УИИЯЛ УрО РАН.

Vladõkin 1994 = Владыкин Владимир Емельянович. 1994. Религиозно-мифологическая картина мира удмуртов. Ижевск: Удмуртия. 
Vladõkina 1997 = Владыкина Татьяна Григорьевна. 1997. Удмуртский фольклор: проблемь жанрово эволюиии и систематики. Ижевск: УИИЯЛ УрО РАН.

Vladõkina, Gluhhova 2011 = Владыкина Татьяна Григорьевна; Глухова Галина Анатольевна. 2011. Ар-год-берган: Обряды и праздники удмуртского календаря. Ижевск: УИИЯЛ УрО РАН.

Nikolai Anisimov on folklorist (PhD). Ta töötab praegu Tartus, Eesti Kirjandusmuuseumi folkloristika osakonnas teadurina. Tema peamised uurimisteemad on udmurdi rahvausund, etnolingvistika ja rahvaluule. 


\section{Summary: The chekan commemoration ritual in the cultural landscape of the contemporary Udmurt village}

\section{Nikolai Anisimov}

In investigating the chekan ritual of commemorative sacrifice carried out in Kalašuri and Dubrovski Villages in the Kiyassovo region of the Udmurt areas, it emerged that certain changes had taken place at various levels. The term chekan has become demythologised in the Udmurt language, but scholars believe that its roots go back to Turkic languages, and that as a cultural sign it means 'offering sacrifice/sacrificing' and is related to the cult of the dead. Commemorative practices that bear some likeness and similarity have been seen in the traditions of local groups among the Udmurt peoples, as well as among other Finno-Ugric peoples (the Zyrian and Perm Komis, and the Maris) and neighbouring peoples (Russians and Chuvass). Yet chekan is a unique ritual with specific attributes: it takes place only in June of leap years and is dedicated to those who died abroad, loved ones buried elsewhere and people who committed suicide. Through the commemoration, the Udmurts in this group devote attention to their 'special' category of deceased, the belief being that otherwise they may become demonic spirits. Research trips spanning sevaral years (2008, 2012 and 2016) have shown that the traditional structure and rules governing the ministrations have changed. For example, the sacrificial animals are not bled on the eve of the ritual, but on the day of the ritual itself. The ritual food is no longer cooked all night long but from morning to mid-day, and the ceremony no longer is presided over by a priest. Both linguists and the author have observed that fewer and fewer people take part in the ritual and people living in more distant parts no longer make the trip, which makes the older generation concerned. It is presumed that the ritual was previously held every three years, as in the case of similar customs mentioned in scholarly literature (Chekas'kon Chokas'kon) and only later was it scheduled to coincide with leap year, referring to the symbolic semantics of the year with the extra day. The biggest changes concern the site of chekan. In 2008 and 2012, the ritual and the rites for the departed souls were relocated, without any procedures related to the change of venue, but solely based on consensus reached by local inhabitants. The main reason cited for the change of venue is that the original place had become overgrown by brush, and it was difficult to reach the original sacral 'centre' and the spruce tree where the offerings were laid. The rituals carried out in 2008, 2012 and 2016 also pertained to another shrine on the village's ethnocultural landscape, the sacral place where once the worship was held in honour of the god Aktash. This led a number of older inhabitants to enquire into the feasibility of the whole development. The given shrine took on a double sacral quality as fieldwork showed that among young people, knowledge of this place, which became inactive in the 20th century, was no longer salient. All of the topographical sites where the sacrifices took place in recent years are marked with the commemorative ritual in question. 
To sum up, it can be said that the chekan, a commemorative ritual in the calendar cycle of the Udmurts of Kiyassovo region, is changing, which is leading to a transformation in the village's cultural landscape. The spatial changes related to the local population's sacral sphere lead to a specific mode of behaviour and regimentation of rites in space and time. 


\section{Резюме: Поминальный обряд чекан в этнокультурном ландшафте современной удмуртской деревни}

\section{Николай Анисимов}

Исследование бытующего на сегодняшний день поминального жертвоприношения называемого удмуртами дд. Калашур и Дубровский Киясовского района Удмуртии Чекан показало некоторые изменения на раздичных уровнях обряда. К сожалению, само понятие в удмуртском языке деэтимологизировано, однако размышления ученых сводятся к тому, что этот обряд восходит в тюркским языкам и в своем культурном значении трактуется как «предлагать жертву/жертвовать» связанному с культом предков. Близкие и в какой-то степени схожие практики поминовения покойников встречаются в традиции других локальных групп удмуртов, а также финно-угорских (комизыряне, коми-пермяки, марийцы) и соседних народов (русские, чуваши). Несмотря на это, Чекан является уникальным в своем роде ритуалом, выделяющимся своими особенными чертами: проводится лишь в високосные года, в июне месяце для умерших на чужбине, не захороненных на местном кладбище и совершивших суицид. В этом действии рассматриваемая группа удмуртов проявляет заботу и внимание к своим «особым» покойникам, чтобы не оставить, не обделить их, иначе они могут превратиться в злобных духов. Проводившееся в течение нескодьких лет подряд исследование (2008, 2012 и 2016 годы) позволяет говорить о том, что традиционная структура обряда и регламент действий претерпел некоторые изменения. К примеру, жертвенное животное режут уже не вечером предыдущего дня, а в день самого Чекана; ритуальноеблюдо варится не в течение ночи, а сутра до обеда; исчезло из обряда основное лицо церемонии - жрец, руководящий сакральными действиями. Как отмечают информанты и как удалось заметить лично, все меньше людей стали принимать участие в ритуале, перестали приезжать живущие в других краях односельчане. Все эти факторы вызывают некоторую озабоченность у старшего поколения. Если говорить о темпоральном коде ритуала можно предположить, что обряд, скорее всего, прежде проводился раз в три года как, например, в других случаях упомянутых в научной литературе (Чекаськон/ Чокаськон), и лишь позднее он был закреплен за високосным годом, со ссылкой на его симводико-семантическую сторону. Более значительные трансформации касаются локуса проведения обряда Чекан. В 2008 и 2012 году место проведения ритуала и проводов душ усопших было перенесено, при этом без всяких сопутствуюих изменению сакрального пространства действий, а дишь по взаимной договоренности местных жителей. В качестве основных причин изменения указывается то, что изначальное место заросло деревьями из-за чего трудно пройти к исконному сакральному «центру» и ели подношений поминальных даров. Проведенные в последние годы ритуальные действия (2008, 2012 и 2016 годы) затронули другой старинный и священный локус этнокультурного ландшафта деревни - Акташ. В итоге пространственные трансформации актуализировали среди старшего поколения нарративы об 
этом сакральном месте, где когда-то проводились моления в честь божества Акташ. Это повлекло за собой проблемы для некоторых старожилов и поставило вопрос о возможности всего происходящего. Получается, что этот локус получил двойное сакральное значение. Но, полевые сведения показали, что знания об этом, упраздненном еще в начале XX века, месте не актуальны среди молодого поколения. Вместе с тем, маркером данного поминального обряда отмечаются все топографические объекты, где в последние годы проводилось жертвоприношение.

Таким образом, поминальный обряд Чекан, включенный в календарный цикл узколокальной группы удмуртов Киясовского района Удмуртии, на сегодняшний день претерпевает определенные изменения, которые ведут к формированию нового облика культурного ландшафта деревни. А пространственные изменения, связанные с сакральной сферой местного населения, ведут в свою очередь к особому поведению и регламентации действий человека в пространстве и времени. 